\title{
Tongue Neoplasm
}

National Cancer Institute

\section{Source}

National Cancer Institute. Tongue Neoplasm. NCI Thesaurus. Code C3416.

A benign or malignant neoplasm involving the tongue. 